\title{
The Cooperation between China and Ukraine in Space Exploration: Genesis and Development ${ }^{1}$
}

\author{
Bo Ma \\ Ph.D. in Law, Professor, Guangdong University of Petrochemical Technology \\ (Maoming, China) \\ E-mail: gdjasonma@gdupt.edu.cn \\ https://orcid.org/0000-0003-3121-571X
}

\section{Larysa Soroka}

Ph.D. in Law, Associate Professor, Scientific Institute of Public Law (Kyiv, Ukraine)

E-mail: lsoroka_kw@ukr.net

https://orcid.org/0000-0002-6979-6049

Ma, Bo, and Larysa Soroka (2020) International Legal Regulation of the Missile Technology Control Regime in the Aspect of Private Space Company Activities. Advanced Space Law, Volume 5, 58-70. https://doi.org/10.29202/as1/2020/5/6

Mainly, the studies of China-Ukraine relations have focused on topics such as trade agreements, commodity exports, investment, migration, and geopolitical implications for the post-Cold War world order. The issue of space cooperation has been almost completely absent in the studies of ChinaUkraine cooperation, despite the central importance of space technology for many spheres of life, which have stimulated research and political participation since the beginning of the millennium. Bilateral cooperation on space exploration between China and Ukraine began in 1992 and has already celebrated its twentieth anniversary. This cooperation is an important determinant of what is considered "new" or "modern" geography of China-Ukraine cooperation. In this article, the study of collections, legal documents, and interviews enables to analyze the strategies of cooperation between China and Ukraine in space briefly.

Keywords: bilateral relations, space programs, White Paper, space exploration, cooperation, law.

Received: March 01, 2020; accepted: April 07, 2020

\footnotetext{
${ }^{1}$ The Ph.D start-up fund project (2019BS007) of Guangdong Institute of Petroleum and Chemical Industry funded.

(C) Ma, Bo, 2020.

(C) Soroka, Larysa, 2020.
} 


\section{Introduction}

Outer space is a common property of all mankind, and all countries of the world have an equal right to freely explore, develop and use outer space and its celestial bodies, moreover, in all countries of the world the outer space activity should promote economic development and society of all countries. Progress should promote the security, survival, and development of humanity and promote the friendly cooperation of the peoples of all countries.

Primarily, the history of space exploration is associated with the history of the "space race" of the 50s of the last century and its two main leaders - the United States and the USSR. The technologies invented in these countries have been further developed in other countries. They were the first and active participants in the exploration of outer space, as well as countries successful in their missions.

Most people will not directly associate China and Ukraine with the start of the aerospace industry, although some parallels exist. For example, discoveries made by the Chinese during the Song Dynasty in the 1200s, that is, the invention of an early form of a rocket using gunpowder, ${ }^{2}$ can be directly associated with the history of space exploration.

With regard to Ukraine, scientists have always been and are its main asset. The vast majority of leading rocket engineers of the Soviet era either came from Ukraine or worked in Ukraine. It was thanks to them: Sergei Korolev, Valentin Glushko, Mikhail Yangel, Vladimir Chelomey, that the majority of launch vehicles were created, both for the military and peaceful space. The first satellite and the first man were launched into outer space, and the orbital stations reached Moon, Venus, Mars, etc. (Zhuravlov \& Halunko, 2019). In Ukraine, about 30\% of the industrial, scientific, and human resources of the former Union are located, as well as worldknown PA Yuzhmash, Yuzhnoye State Design Office, PJSC HARTRON, SE IA Kievpribor and other collectives. Ukraine possesses the whole process of space technology construction, from design to production and operation in space. Over 25 years of independence, more than 140 launches of domestic missiles have been carried out, 375 spacecraft, made to order from 25 countries, have been launched into orbit (Kuznetsov, 2018).

The current economic situation of Ukraine is characterized as deeply critical. But this is not a reason to forget about the space industry, which will enable us to bring the country out of crisis. After all, the industry is connected with nearly every human activity on Earth: agriculture, medicine, communication, television, remote sensing of the earth, weather forecasting, magnetic disturbances (space weather), and more.

Many countries recognize modern China as an economic superpower, with the largest economy in the world. Moreover, China's space technology comes first. Thus, cooperation with China in the aerospace industry becomes very attractive.

China is also interested in cooperation with other countries in the field of aerospace industry to achieve its own national goals. For example, to access the resources and technologies of other countries.

${ }^{2}$ The word "rocket" first appeared in "Wei Lue", quoted by Pei Songzhi in The Three Kingdoms and the Period of Emperor Wei Ming. In the second year Wei Taihe (228 years), Zhuge Liang from the Kingdom of Shu, sent troops to attack Chen Tsang. Wei Shaw made Hao Zhao "shoot down a ladder from a rocket". According to the "Song Story". three years after Kaibao (970), Feng Jisheng introduced how to make rockets before the government of the Song Dynasty. "Wu Jing Sui Yao" formally listed the shape of the rocket, with drawings, this is the first rocket drawing in the world. https://zh.wikipedia.org/ zh-hant/火箭 
In 2007, Li Xueong, vice-minister of science and technology, said that China hopes to become the 17th country to join the International Space Station (ISS) (Xiaofang, 2011). In 2012, during a meeting of agency leaders in Quebec, Vladimir Popovkin, the head of the Russian Space Agency Roscosmos, and Jean-Jacques Dordain, the head of the ESA, announced that they were open for cooperation with China in the framework of the ISS (Ebeling, 2016: 9). However, the US did not give its consent to China's participation in the ISS (An Act, 2011).

Since Russia is skeptical about providing China with military technology because of the high probability of copying, to receive them from Ukraine gives the PRC two advantages: first, China will receive technology, and second, it will strengthen its position in a country that Russia considers its sphere of influence. In addition, China plans to implement its global strategy to increase exports and investment in potential markets located between Russia and the EU (Goncharuk et al., 2016).

While the United States is very reluctant to cooperate with China in the field of aerospace technology, the EU and Ukraine become increasingly attractive and sustainable partners for China. Since China seeks to strengthen its position in Europe and Ukraine seeks to expand its presence in Central Asia, both countries are among the States with space status, both countries are of interest to each other in the field of building bilateral relations in the space sector.

Similar to China, Ukraine is considered an agricultural country. However, the American physicist, Dr. Michio Kaku, argues that nations that believe only in agriculture are doomed to poverty (Kaku, 2019). Therefore, both countries actively develop science and innovative technologies in all sectors of the economy.

In China, a specific shortage of specialists and technologies in the field of metalworking, mechanical engineering, as well as in aviation and space industries exist. Ukraine has a powerful scientific and industrial base, a sufficient number of specialists, and a high level of education.

Regarding the policies of both countries towards each other, China supported Ukraine not only in territorial integrity but was one of the countries that provided nuclear security guarantees to Ukraine in 1994. The Joint Declaration, signed by the two presidents, clearly stated that China recognizes consistently Ukraine's sovereignty and territorial integrity, as well as it is committed to ensuring its earlier security guarantees. For its part, Ukraine supports the "One-China" concept, that is, opposes Taiwan's independence by pledging not to have any official contacts with this Chinese province, as stipulated in the Joint Statement between the People's Republic of China and Ukraine signed on September 2, 2010 (China, 2010). This position on the part of the Ukrainian government will further support Ukraine's international arena and bring the two countries closer in geopolitical terms.

With the beginning of the Revolution of Dignity, these relations were put on hold. China's leadership did not support Yanukovych's approach to the resolution of the political crisis. When the State Duma of the Russian Federation issued permission on 1 March 2014 to use its own troops against Ukraine, China took a clear position as soon as on 2 March in support of Ukraine's independence, sovereignty and territorial integrity, and urged the sides to use dialogue and negotiations based on international law and international relations for peace and stability in the region. However, the Chinese representative expressed the opinion that there were certain causes of events in Ukraine. This approach enabled to interpret China's official position very widely and differently (Goncharuk et al., 2016: 37). Somewhat later, Qin Gang, a spokesman of China's Ministry of Foreign Affairs, clarified his country's position: "China always advocates respect for the sovereignty and territorial integrity of any country. 
China always sticks to this main course of foreign policy. The Chinese side believes that the Ukrainian crisis has complicated historical background and is caused by modern realities. All this must be analyzed and taken into account when resolving the crisis"(China, 2014).

As the revolution events unfolded, China urged the parties in Kyiv to resolve conflicts based on the law and legitimate interests of the Ukrainian people. Unlike Moscow, which forced Yanukovych to take more active and tough actions to curb the protests, China strongly condemned acts of violence (Foreign, 2014).

Thus, the historical prerequisites for the establishment of China-Ukraine bilateral relations are:

a) the similarity of both countries' positions on the key problems of contemporary political development (to reduce the influence of Russia and the US, to be full members of the Space Club and to participate in joint international projects, etc.);

b) the absence of acute problems in bilateral relations;

c) the desire to integrate into the world economic community through the development of an innovative economy, in particular, space industry;

d) the possibility of sharing resources, while for Ukraine, China's investment resources are of interest. For China, the scientific resources of Ukraine are relevant.

Each state aims to improve life, create new conditions for the society that would be positive changes on the basis of economic, political, and social principles of development. Therefore, the strategic plan of the future is extremely important, taking into account the globalization processes of today. Consequently, it is essential to consider ways of productive development of cooperation between these countries.

Therefore, the study aims to analyze the legal framework for cooperation between China and Ukraine in the space sector by comparing space programs and State policies to find motives or possible obstacles to China-Ukraine participation.

\section{Space programs of China and Ukraine}

International and national politics play an important role in the space sector. Developed on the basis of international principles, national space programs will not only determine the policies of each State in space exploration, but also determine the rules of the game for partnerships.

\section{China}

China's rapid economic development has been mostly driven by cheap labor and resources. After entering the next stage, China has developed a new development strategy based on innovation. Today, China is pursuing an innovative development strategy aimed at deepening the reform of the scientific and technological system, stimulating technological and economic integration, building a technological innovation system combining production, science, and research, and based on market-oriented entrepreneurship. China strives to improve knowledge of the innovation system and increase the research level.

At the opening ceremony of China's First International Import Expo, President of the People's Republic of China Xi Jinping stated that economic globalization was an irreversible historical trend that had given a strong impetus to the development of the world economy 
(Speech, 2019). Considering that the topic of the event was "New Epoch, Joint Future," it is not surprising that the key points of the speech of the Chinese helmsman were as follows:

a) open cooperation is an important driving force in strengthening the international economy and trade;

b) innovations, in other words, only those who are brave enough to implement changes and transformations will be able to make a breakthrough in the development of the global economy;

c) inclusivity and universal preferences, promotion of joint development of all countries in the world.

Therefore, the Chinese leadership has defined the socio-economic policies of the country for many years, putting at its core a triad: openness-innovation-inclusivity.

The history of China's space programs can be viewed in the context of four significant periods: 1) 1956-66; 2) 1966-76; 3) 1977-86; 4) 1986 - present time (Chen, 2016).

In turn, the fourth period may be divided into subperiods: a) 1986-2000; b) 2000-2011; c) 2011-2016; d) 2016-2021.

Not all the periods of development of China's space programs will be analyzed in detail. Still, the period from 2016 to the present will be under focus, i.e., since the adoption of China's last policy document White Paper (White Paper, 2016), published on December 27, 2016, which determined the country's policy for the next five years in the field of space activities ${ }^{3}$.

It should be noted that the White Papers on China's Space Activities are not just a set of texts with generalizations and planning measures for space activities. This is the scientific and practical matter of building a new China, as a leading spacefaring nation, which considers space as an essential tool for realizing the dream of the Chinese society, as an independent world leader in science and technology (Yeshchuk \& Vasina, 2019: 141).

In the socio-economic development of the country, Chinese leadership focuses on science. Science and innovation should be a driving force for China's development. In this regard, the Government of the country provides comprehensive support for science and innovation development. In February 2006, the State Council of the PRC published An Outline of the National Medium- and Long-Term Program for the Development of Science and Technology (2006-2020). The Program includes 15 important objectives that are scheduled to be completed over 15 years. They concern some strategically important and relevant fields, such as informatics, bionics, energy, ecology, healthcare, etc.

Moreover, plans involve building large-scale aircraft for civilian aviation, launching human-crewed space shuttles, and exploring the moon. According to this program, by 2020, funding of research and development will increase from $1.33 \%$ of GDP up to $2.5 \%$. The share of GDP created by scientific and technological progress will exceed $60 \%$ of the country's GDP (Ukraine - China, 2018).

China develops legal regulations in the field of international cooperation in space, first and foremost, according to the provisions and principles approved by the United Nations (International Declaration on Space Cooperation) (A/RES/51/122, 1997). China advocates strengthening international exchanges and cooperation in the space sector according to the principles of equality, mutual benefit, peaceful use, and joint development.

${ }^{3}$ In China, the exploration and use of outer space is carried out in accordance with the so-called White Papers on Space Activities, which are regularly (every five years) adopted by the State Council of China in 2000, 2006, 2011 and 2016 
To implement plans adopted, since 2018 the Chinese government took a number of important measures, including reducing the burden on enterprises, reducing tax benefits, reducing budget expenses, reducing administrative permits and providing enterprises with a "single service" to help reduce the costs of the corporate system to make administration as desirable as possible for business and minimize corruption mechanisms.

The space sector is no exception; that is, China continues to increase its investment and encourage the creation of a diversified and multi-channel system to maintain sustainable development of the space industry. With China's 2011 Space White Paper, the Chinese government has started active commercialization of space activities (White Paper, 2011).

With the initial creation and continuous improvement of the socialist system and market economy, with the development of space activities in China, the role of the State was fundamental. According to the first White Paper (2000), the State-controlled space activities through macro control (White Paper, 2000), through coordinated development of space technologies, space science, and promoted research, as well as the development of basic technologies, in the space industry.

Moreover, the State assumed the responsibility for the legal support of space activities: to strengthen the legal system; to construct and manage policies; to create the order of aerospace law; to regulate, to formulate technological policy in the aerospace industry; to guarantee an orderly and standardized development of aerospace activities.

However, in contrast to Ukraine, where space activities are regulated by the Basic Law of Ukraine "On Space Activities" (On space, 1995), in China, by-laws carry out such regulation. The necessity of adopting the law was discussed at the National Meetings of China and in the scientific community (Xiaodan, 2018; Zhenjun, 2014), but it was not adopted. In this regard, Prof. Zhang Zhenjun argues that "...the current regulation on space activities falls short of the rule of law, as showcased by an insufficient supply of legal institutions, inadequate awareness of the rule of law, and space regulatory frameworks that require further reform. Top-level planning, enhanced space legislation, and a combination of promoting the rule of law in China's space industry and deepening reform on space regulatory frameworks are needed to start a new age of China's space industry under the rule of law" (Zhenjun, 2014).

China should be pragmatic regarding space legislation in terms of commercialization of space, and the most important legal issues should be regulated in law, that is, establish a mechanism for protecting intellectual property, mechanisms for export control, and dispute resolution (Long, 2016).

Moreover, in 2020, a Chinese private company is about to launch a reusable spacecraft for the first flight. Its most giant version will be able to lift 20 people to a height of $130 \mathrm{~km}$ and provide them with four minutes of weightlessness. Logically, it is precisely in this field of space services; legal challenges occur more frequently than financial ones. For example, the legal status of space tourists and members of space taxi crew requires regulation. Their subjective rights and legal obligations should be clearly stated. The legal responsibility of each member of the space mission should be determined (Yeshchuk \& Vasina, 2019: 142).

Although Chinese and Ukrainian space programs are structured differently, they have much in common. 


\section{Ukraine}

Space activities in Ukraine are governed by the National Space Program of Ukraine, developed for five years, and approved by the Verkhovna Rada of Ukraine upon submission by the Cabinet of Ministers of Ukraine. The State Space Agency of Ukraine, together with the central executive bodies and the National Academy of Sciences of Ukraine, is responsible for the development of the National Space Program of Ukraine, based on the purpose and basic principles of space activity of Ukraine (Soroka, 2019). Since 1992, five Space Programs have been adopted and implemented in Ukraine.

The sixth one has never been adopted. To date, only the Concept of National Targeted Scientific and Technical Space Programme 2018-2022 has been approved by the Resolution of the Cabinet of Ministers no. 629-r of September 5, 2018. It aims to “... increase the efficiency of the use of space potential for solving urgent tasks of socio-economic, environmental, cultural, information, scientific and educational development of society, to ensure the realization of the State's interests in the field of defense and national security" (On approval, 2018). According to the Government of Ukraine, this mission should be implemented by expanding cooperation, first of all with the EU, by increasing the number of new specialists in educational institutions and retaining old staff (by raising salaries), by allowing the private sector to participate in space activities.

Moreover, to increase the efficiency of space activities, to solve urgent problems of national security and defense, and to realize the geopolitical interests of the State, to promote the socio-economic, scientific, educational and ecological-cultural development of society, to increase the prestige of Ukraine as a space State on the world stage, to turn the space industry of Ukraine into a multiplier of high-tech development of the domestic economy, the Conception of implementation of the state policy in the field of space activities for the period up to 2032 was approved by order of the Cabinet of Ministers of Ukraine of March 30, № 238$\mathrm{R}$ (Conception, 2011) (hereinafter the Conception).

The result of its implementation, that is, the quantitative measurement of its goals, is decisive for public policy. According to this Conception, the state has declared its results, methods, and ways of achieving these results. The primary way to solve the existing problems of the space industry of Ukraine is seen through the improvement of the mechanism of providing state support and ensuring the investment attractiveness of space activities. Analyzing the components of the organization of space activities in Ukraine, it can be noted that the state has taken the lion's share in ensuring the development of the industry through two interrelated processes - state support and investment attractiveness of space activities, which are noted in the regulatory acts (Soroka, 2019).

Therefore, the rules and principles of "classical" International Space Law have been implemented sufficiently enough in the national law of Ukraine to be content with international obligations. Nevertheless, as we have repeatedly stated in our publications (Soroka, 2019), current studies and practice indicate that the main tasks facing Ukraine's space law are:

a) strengthening the legal protection of investors in Ukraine;

b) initiation of tax and other incentives for forming long-term investment resource proposals;

c) demonopolization of the state for space activities;

d) reducing the involvement of regulatory authorities in economic activity; substantial simplification of procedures for issuing permits; 
e) return of State controlling functions over the space activities of all entities through a mechanism for licensing such activities;

f) proper regulation of ownership of investment assets and transparent integration of such assets.

Joint projects implemented by Ukrainian and Chinese specialists are in the fields of high technology, new materials, environmental protection, and drug production. Cooperation with the PRC in the space industry is particularly beneficial for Ukraine as it enables the conscious realization of the Ukrainian space potential. In Ukraine, funds are limited in this area. Instead, China is one of the leading investors in space exploration. Nowadays, Ukraine executes 21 contracts with China totaling more than USD 67 million, implements its 5 -year space industry development programs, and has the concept of space activities by 2032. For its part, China has a space program very ambitious and sufficiently funded. China is interested in importing high-tech finished goods, and Ukraine should take this into account and use it in the interests of national production (Goncharuk et al., 2016).

Therefore, the policies of both countries in space have both commonalities and differences. The common features are:

a) Outer space is a common property of all mankind, all countries of the world have an equal right to freely explore, develop, use outer space and its celestial bodies;

b) Outer space activities in all countries of the world should promote their economic development;

c) The key role of the State is in the organization, regulation, control and legal support of space activities;

d) Commercial private enterprises have equal access to space activities along with state-owned ones, subject to compliance with requirements for such activities;

e) Progress in space shall ensure security, sustainability, and cooperation.

The differences are:

a) While in Ukraine, laws and by-laws regulate space activities, in China, only regulations govern them;

b) While China's space programs are funded in full, in Ukraine, they are financed with a constant deficit;

c) While in China, the government of the country considers the development of space as one of the priority areas both de jure and de facto, in Ukraine, de jure - yes, de facto - no.

\section{Legal framework for China-Ukraine bilateral cooperation in space}

Cooperation in science and technology is one of the main areas of bilateral relations between China and Ukraine. The priority areas of participation in the field of scientific and technical cooperation are energy efficiency, aviation, shipbuilding, environmental management, development of aerospace, information and communication technologies, training, and internship of graduate students and young scientists.

The legal framework for cooperation in space are legal regulations, such as the Agreement between the Government of Ukraine and the PRC Government on cooperation in the field of exploration and use of outer space for peaceful purposes (20 may 1996), the Memorandum 
of Understanding between the State Aviation Administration of Ukraine and the Directorate General of Civil Aviation of the PRC (25.06.1999), the Protocol between the Ministry of Industrial Policy of Ukraine and Chinese Commission for Defence Science, Engineering and Defence Industry on cooperation in the aeronautical engineering (18 November 2002), the Program of Ukrainian-Chinese Cooperation on exploration and use of outer space for peaceful purposes for 2011-2015 (02 September 2010), the Agreement on strategic cooperation between the Joint-Stock Company "Motor Sich", State Enterprise "Ivchenko-Progress" and the Chinese Aviation Corporation "AVIC International Holding Corporation" (04 December 2013 p.), the Protocol of the Third meeting of the Subcommission in the field of exploration and use of outer space for peaceful purposes of the Commission for cooperation between the Government of Ukraine and the Government of the PRC (07 April 2016 p.), the Protocol of the Fourth meeting of the Subcommission in the field of outer space of the Commission for cooperation (for 2016-2020) between the Government of Ukraine and the Government of the PRC (21 November 2017 p.).

Mainly, the Subcommission on Space Cooperation, created to replace the UkrainianChinese Subcommission in the field of exploration and use of outer space for peaceful purposes, which existed from 1997 to 2010, is in charge of bilateral space relations. During this period, two joint five-year cooperation plans (for 2001-2005 and 2006-2010) were implemented, as well as the Space Cooperation Plan for 2011-2015 was adopted.

At the beginning of November 2018, the Fifth Meeting of the Subcommission on Space Cooperation took place in Beijing. The parties reviewed the status of implementation of the Program of Ukrainian-Chinese Cooperation and approved its new version. The updated version of the Program contains more than 80 active points and a list of long-term perspectives for cooperation: joint activities to prevent natural disasters, plans against space debris, and space exploration.

\section{Critical outcomes of bilateral China-Ukraine relations in space}

China and Ukraine do not provide complete open official information on aircraft and missile science, which complicates the analysis, including the analysis of trends and opportunities for further cooperation between China and Ukraine. However, available open sources enable to summarize some of the outcomes.

In the space segment of bilateral cooperation, the developments should be highlighted as follows (Badrak, et al., 2009: 63):

a) the exchange of information on the technical parameters of the Chinese Environment-1B project and the Ukrainian Sich-2 project to establish mutually beneficial cooperation in the field of space data exchange;

b) delivery to China of a laboratory facility (including the transfer of production technology) for manufacturing non-plasma engines for spacecraft;

c) closeness and interchangeability of the Ukrainian UNOSAT project and the Chinese seismic electromagnetic satellite project give the possibility of establishing mutually beneficial cooperation on these projects.

According to the Agreement between Ukraine and China, Kharkiv Military University has started training Chinese air defense specialists (Training Aviation Command began operating in the military town "Rogan-1" near Kharkiv). It is possible that in the future Ukraine will 
begin to train cadets-pilots from the PRC, as well as provide medical support for the training of astronauts, which is especially important for the implementation of the Chinese Space Program "Project 921" (Joint Project, 2018).

To date, Ukraine's position in the space sector is the strongest in the launch services market. While China is interested in developing its satellite navigation system, Ukraine is interested in acquiring microelectronics technology and investing. Therefore, constant and promising cooperation between the PRC and Ukraine can be established and stabilized in these sectors. However, nowadays, Ukraine should be more actively involved in projects within the framework of cooperation with China on legal, clearly stipulated contractual bases with the maximum contract validity to enhance its capabilities in this sector and gain competitive advantages in international markets.

Promising forms of scientific and technical cooperation, such as the creation of technoparks, incubators, engineering and technology transfer, etc., are being implemented between China and Ukraine.

Moreover, in the People's Republic of China, the first industrial zones were established back in 1980. Currently, there are 54 technoparks in the country that provide about $10 \%$ of GDP and accumulate $30 \%$ of FDI. In Ukraine, 12 industrial parks are registered, and only a few of them are under construction. The rest is not functioning (Natalushka, 2017).

The creation of technoparks will provide potential foreign investors with new opportunities for preferential taxation, as it has been done in Singapore. With such technoparks, the owner will be able to draw up all the necessary permits for Chinese investor companies, eliminating the need to run around the offices of officials.

Along with the positive points in bilateral relations between China and Ukraine, factors that hinder the development of interstate partnerships remain and need to be addressed. First, these are a narrow foreign policy orientation of the Government of Ukraine to the countries of Europe and the USA, the inaction of the Ukrainian side in holding official meetings, visits to China with the participation of the first persons of the State, the absence of political continuity (every time after a change of power, a new plan, a new strategy of development occur) and the presence of corrupt schemes in legal regulation (Natalushka, 2017). Second, insufficient explanatory work on the meaning and ultimate purpose of socio-political transformation in Ukraine (for example, the Chinese will understand de-sovietization as a rejection of the negative heritage of the USSR and will not understand decommunization, because communism remains the official ideology of the PRC) (Goncharuk et al., 2016: 38). Third, the difficulty of a Ukrainian visa for the PRC citizens remains a huge obstacle to establishing effective relations with China, and there are problems with guaranteeing the safety of Chinese living in Ukraine, their businesses, and property.

At the present stage, China and Ukraine have every opportunity to realize a considerable potential of bilateral cooperation in science, technology, and education, to be in close relation with the international scientific and technological community, and to participate in creating an innovative global society (Joint, 2018).

\section{Conclusions}

China's role in the world becomes more significant. Expanding political, economic, cultural, and other relations with this country is one of the critical areas of Ukraine's foreign policy. Before the declaration of independence in 1991, Ukraine, as part of the USSR, had 
been building its relations with the People's Republic of China within the framework of the all-Union foreign policy doctrine. Only after the collapse of the USSR and the proclamation of its independence an independent policy became possible.

Ukraine and the PRC are known to have much in common. This concerns geopolitics, which broadly defines the role and place of Ukraine and the PRC not only in the Eurasian region but also in the broader, global geopolitical context. The countries have mutual economic interests and close positions on the key problems of contemporary world political development. Both states face similar internal socio-economic issues. In both countries, a transition to a market economy occurs, a desire for a policy of openness exists. Both countries are in the Eurasian region, are neighbors of Russia, and are in the interests of the United States of America.

The foreign policy of both countries is based on a realistic consideration of their national interests. Ukraine is an essential factor in European and world politics. It is respectful of the PRC's growing role in contemporary international relations. Ukraine and the PRC have been productively and consistently working and coordinating their policies at the UN and other international organizations.

According to Meng Hin, despite a great interest of politicians and the public regarding the issue of China-Ukraine cooperation in the 1990s of the twentieth century, it remains studied incompetently. However, for the first time in the history of the two countries, their relations have begun to develop on a broad legal basis (Meng, 2005). This requires an in-depth study of the various strands of relations between Ukraine and the PRC. The study of this issue will enable us to understand the main trends in the development of relations between the States and to offer recommendations on the implementation of comprehensive cooperation.

Therefore, considering the benefits of scientific and technical cooperation, and existing areas of cooperation, the authors propose the following strategic approaches to expanding science and technology-based relationships, which form an overall strategy for long-term cooperation in space that could, in the long run, bring China and Ukraine to a new level of development, increase their competitiveness in the world markets: joint research and development; exchange of scientific and technical information and documentation, samples of products and materials, as well as the exchange of know-how and licenses on a compensatory basis; organization of scientific-technical seminars, symposia and scientific conferences, etc. Besides, the successful commercialization of space exploration products requires to develop and adopt regulatory acts promptly to create the necessary legal platform to realize the prospects for both China and Ukraine.

In conclusion, some truths are eternal. Ancient Chinese philosopher Confucius said: "Those who do not care about their future will be in trouble soon." If Ukraine had perceived the recommendation of its first president, "science can wait" as a ridiculous joke. Our current "famine of science" might not have occurred, or, as our Western colleagues say, "innocide" instead of innovation (Driga, 2017: 61).

\section{[ㅁ] References}

A/RES/51/122 (1997) Resolution adopted by The General Assembly [on the report of the Special Political and Decolonization Committee (Fourth Committee) (A/51/590)]. Declaration on International Cooperation in the Exploration and Use of Outer Space for the Benefit and in the Interest of All States, Taking into Particular Account the Needs of Developing Countries. https://undocs.org/en/A/RES/51/122 
An Act Making consolidated appropriations for the Departments of Agriculture, Commerce, Justice, Transportation, and Housing and Urban Development, and related programs for the fiscal year ending September 30, 2012, and for other purposes (2011) PUBLIC $L A W$ 112-55-NOV. 18, 2011. https://www.congress.gov/112/plaws/publ55/PLAW112publ55.pdf

Badrak, V., Zhurets', S., Bohdanov, D., Kopchak, V., Nabochenko, O., Yarovyy, A. (2009) Ukrayina - Kytay: vid proektiv do stratehichnoho partnerstva. Kyyiv: Tsentr doslidzhen', armiyi, konversiyi i rozzbroyennya.

Chen, Yanping (2016) China's space policy-a historical review. Space Policy. Volume 37, Part 3: 171-178. https://doi.org/10.1016/j.spacepol.2016.12.001

China Calls on all Interested Parties to Make Efforts to Political Settlement of the Crisis in Ukraine - the Ministry of Foreign Affairs of China (2014) Russian.people.cn. http:// russian.people.com.cn/31521/8568055.html

China has promised not to use nuclear weapons against Ukraine (2010) TSN. Ukraine. https:// tsn.ua/ukrayina/kitay-poobicyav-ne-zastosovuvati-yadernu-zbroyu-proti-ukrayini.html

Conception of implementation of the state policy in the field of space activities for the period up to 2032 was approved by order of the Cabinet of Ministers of Ukraine of March 30 2011, № 238-R (2011) https://zakon.rada.gov.ua/laws/show/238-2011-\%D1\%80

Driga, Sergiy (2017) The Innocide is a substitute for international politics. Problems and prospects for the development of innovative activities in Ukraine. KNTEU. https:// knute.edu.ua/file/MzEyMQ==/7ae27cf3ff4a4d4b3ee985f220617e75.pdf

Ebeling, Petra (2016) China's space program: How cooperation between China and Europe changes as China's space program advances. East Asian Studies, Leiden University. https://openaccess.leidenuniv.nl/bitstream/handle/1887/41982/Thesis\%20Chinas\%20 Space\%20Program\%20-\%2009-08-2016.pdf?sequence=1

Foreign Ministry Spokesman Qin Gang answered a journalist's question regarding the situation in Ukraine (2014) Ministry of Foreign Affairs, the People's Republic of China. https:// www.fmprc.gov.cn/rus/xwfw/fyrth/fyrbthdhdw/t1133559.shtml

Goncharuk, A., Gobova, E., Kiktenko, V., Koval, O., Koshoviy, S. (2016) AUDIT OF FOREIGN POLICY: UKRAINE-CHINA. DISCOUNT NOTE. Institute of Politics. http://sinologist.com.ua/wp-content/uploads/2018/09/Audyt-zovnishnoi-polityky_ Ukr_Kytay-_ukr_inet.pdf

Hung, Zhang (2017) The One Belt, One Way initiative: the risks of counteracting China-Ukraine cooperation and counteracting them. Ukraine-China, Vol. 3 (9). http://sinologist.com. ua/wp-content/uploads/2017/12/ukraine-china-3-9-17.pdf

Joint Projects in Science Will Allow Ukraine and Chana to Come on New High-Tech Manufacturing (2018) Center for Contemporary China "THINK LINK". http://www. tianxia.link/uk/article/7409-spil-ni-proiekti-v-nautsi-dozvoliat-ukrayini-i-kitaiu-viitina-stvoriennia-novikh-visokotiekhnologhichnikh-virobnitstv

Kaku, Michio (2020) Official Website. https://mkaku.org/home/

Kuznetsov, Yevhen (2018) Dvadtsyat' rokiv pislya nevahomosti, abo Trudnoshchi zemnoho tyazhinnya. Pam'yati pershoho kosmonavta nezalezhnoyi Ukrayiny Leonida Kadenyuka. ZN,UA. https://dt.ua/personalities/dvadcyat-rokiv-pislya-nevagomostiabo-trudnoschi-zemnogo-tyazhinnya-271423_html

Long, Jie (2016) China's space station project and international cooperation: Potential models of jurisdiction and selected legal issues. Space Policy. Volume 36: 28-37. https://doi. 
org/10.1016/j.spacepol.2016.05.002

Meng, Hin (2017) Ukrainian-Chinese relations at the end of $20^{\text {th }}$ - beginning of the $21^{s t}$ century. Kyiv Slavic University.

Natalushka, Anna (2017) Legal Aspects of Ukrainian-Chinese Relations. Ukraine-China, Vol. 3 (9). http://sinologist.com.ua/wp-content/uploads/2017/12/ukraine-china-3-9-17.pdf

On Amendments to Some Laws of Ukraine on State Regulation of Space Activity (2019) Law of Ukraine of 02.10.2019 №143-IX. https://zakon.rada.gov.ua/laws/show/143-20

On Approval of the Concept of the National Target Scientific and Technical Space Program of Ukraine for 2018-2022. (2018) Ordinance of the Cabinet of Ministers of Ukraine of September 5, 2018 №. 629-p. https://zakon.rada.gov.ua/laws/show/629-2018-\%D1\%80

On Space Activities. (2015) Law of Ukraine Revision of 28.12.2015. № 122/96-BP. https:// zakon.rada.gov.ua/laws/show/502/96-\%D0\%B2\%D1\%80

Soroka, Larysa (2019) Public Regulation of Space Activities in Ukraine. Advanced Space Law, Volume 4: 68-79. https://doi.org/10.29202/as1/2019/4/7

Speech by President of the People's Republic of China Xi Jinping at the Opening Ceremony of the First China International Import Expo (2019) http://ua.china-embassy.org/rus/ $\mathrm{xwdt} / \mathrm{t} 1627053 . \mathrm{htm}$

Ukraine - China - 25 years of cooperation: results and prospects. One Belt, One Way (2018) Scientific editor Oliynyk Oleh. State Institution "Institute of World History of NAS of Ukraine." http://ivinas.gov.ua/uk/publikatsiji/novi-vydannia-instytutu/ukrainakytai-258786887.html

White Paper China's Space Edition (2000) http://www.cnsa.gov.cn/n6758824/n6758845/ c6772480/content.html

White Paper China's Space. (2011) http://english.www.gov.cn/archive/white paper/2014/09/09/content_281474986284620.htm

White Paper China Aerospace (2016) http://www.cnsa.gov.cn/n6758824/n6758845/c6772477/ content.html

Xiaodan, $\mathrm{Wu}$ (2018) China's Space Law: Rushing to the Finish Line of its Marathon. Elsevier. Volume 46: 38-45. https://doi.org/10.1016/j.spacepol.2018.03.004

Xiaofang, Zhang (2011) The US has consistently rejected China's participation in the International Space Station program. https://china.huanqiu.com/article/9CaKrnJswVW

Yeshchuk, Olga, and Anna Vasina (2019) Chinese Space Law: Problems and Areas of Reforming. Advanced Space Law, Volume 3: 140-150. https://doi.org/10.29202/ as $1 / 2019 / 3 / 12$

Zhenjun, Zhang (2014) Reflections on Promoting the Rule of Law in China's Space Industry. Journal of Beijing Institute of Technology (Social Sciences Edition). http://en.cnki.com. $\mathrm{cn} /$ Article_en/CJFDTotal-BLDS201405019.htm

Zhuravlov, Dmytro, and Andrii Halunko (2019) Features of Legal Support of Space Activities in Ukraine. Advanced Space Law, Volume 4: 116-124. https://doi.org/10.29202/ asl/2019/4/11 